\title{
Managing shared river basins in the Horn of Africa: Ethiopian planned water projects on the Juba and Shabelle rivers and effects on downstream uses in Somalia
}

\author{
A. Elmi Mohamed \\ Department of Land and Water Resources Engineering, \\ Royal Institute of Technology, Stockholm, Sweden
}

\begin{abstract}
The Juba and Shabelle Rivers in the Horn of Africa are shared by Ethiopia, Kenya and Somalia. Most of the rivers' runoff originates from the Ethiopian Highlands. Before entering into the Indian Ocean, the rivers pass through a semidesert area and cross area of border dispute. The rivers are in a war-scarce, warravaged and contentious region. The paper examines the physical and developmental aspects of the two rivers, and analyses resulting trans-boundary river management issues. Methodology used is document and literature reviews, interviews with key persons and other relevant organizations. River master plans and other relevant documents describing policies as well as existing and planned uses were reviewed. The two rivers supply support important economic areas in southern Somalia. As an outcome from their master plans of the river basins, Ethiopia is now planning to build several large dams for hydropower generation and large scale irrigation schemes. No notifications were given to downstream Somalia, which will be the most affected downstream riparian of the projects. These unilateral major water development projects will have substantial adverse impacts on Somalia, as there are no agreements between the nations on sharing river waters. The sum of the existing uses in Somalia and planned ones in Ethiopia will exceed available water resources in the rivers. Potential disputes over the shared rivers are therefore likely to rise. Turning this risk of conflict into a sustainable peace and development in the region, the paper presents existing and potential opportunities for cooperation over the shared water resources for mutually sharing benefits.
\end{abstract}


Keywords: shared rivers, Juba and Shabelle, water projects, cooperation, conflict, Horn of Africa, Somalia, Ethiopia.

\section{Introduction}

Rivers are the most important sources of freshwater, which plays a major role in society's economic development and in maintaining life supporting ecosystems services. In general terms water resources management becomes increasingly critical and as new local and national sources of water become scarce, limited, expensive and difficult to exploit [1], many countries in the arid and semi-arid regions that are facing water crisis $[2,3]$ will be increasingly forced to consider the possibilities of utilizing the water that is available in international river basins. Thus, the concerns relating to the use of international waters are becoming increasingly more important and complex. Because most remaining major easily exploitable sources of freshwater are now in river basins that are shared by two or more sovereign States [2, 4]. Shared rivers in dry climate regions could be a source of conflict or a reason for cooperation between countries sharing them.

The Horn of Africa is a water scarce region where available water resources exist in rivers shared by neighbouring countries. The Juba and Shabelle rivers are shared by Ethiopia, Kenya and Somalia, see figure 1. The region's primary economy is agriculture and there is a desperate need to increase water uses for food and hydropower production. Riparian countries have never discussed cooperation over these rivers [5]. The region is also a war ravaged one.

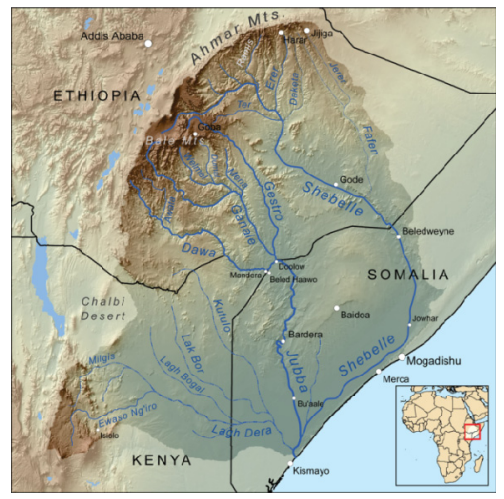

Figure 1: Map showing the Juba and Shabelle river basins in the Horn of Africa.

The overall purpose of the paper is to analyse the management of the international freshwater resources with special focus on the Juba and Shabelle Rivers in the Horn of Africa and to analyse transboundary water management issues. As these rivers have not been studied before from any transboundary perspective, the paper may lead to a determination of how an effective 
management of these international river basins could be approached. The specific objectives are to study how to transform the current situation of zerosum game into plus-sum one through sharing benefits of mutual interest from the common water resources? What are the obstacles for establishing river cooperation? Why was it difficult or impossible to create a collaborative climate? Demonstrating the necessity of river cooperation, what will be the driving force for the required future cooperation over these shared river systems? Another specific objective of this paper is to examine both the existing and planned uses of water and how will they impact on the riparian countries, particularly downstream uses in Somalia.

\section{Methodology and data}

The research design selected for this paper is a qualitative case study analysis. Different methods for data collection were applied. These include document and literature review, interviews, information and data gathered during study visits. Information collected include regional situation on water resources, physical and hydrological aspects of the selected shared rivers, existing and planned water projects and other documents about international waters. Master plans of the Juba and Shabelle rivers both by Ethiopia and Somalia have been deeply reviewed, analysed and examined. The riparian countries' policies towards development of the rivers have been studied and analysed. The paper analyses also the extent to which these rivers' water resources are utilized and planned to develop. Different and competing riparian countries' needs and arguments were matched with the existing internationally accepted water principles. Several study visits to the region were undertaken to meet water institutions and interview relevant people who directly involve in these rivers' management.

\section{Physical geography and the riparian states of the river basins}

\subsection{The Shabelle river}

Originating from the Bale Mountain in the Ethiopian highlands, at an altitude of about 4230 meters above sea level, the total basin area of the Shabelle river is $297000 \mathrm{~km}^{2}$ [6]. Nearly two-third (63.5\%) of the basin area lies in Ethiopia and one-third in Somalia [6]. Within Ethiopia, the river has several tributaries contributing to its runoff. Flowing generally south-easterly direction; the Shabelle River passes through an arid land in the eastern province of Ethiopia cutting wide valleys in southern Somalia. Running a distance of about $2526 \mathrm{~km}$, of which $1290 \mathrm{~km}$ in Ethiopia, the river does not normally enter the Indian Ocean, but into a depression area, where it is finally lost in the sand in southern Somalia, feeding an ecologically sensitive area and recharging areas of groundwater aquifers. Only with exceptionally heavy rains does the Shabelle River break through to join the Jubba and thus succeed in reaching the ocean. 
With an average annual rainfall of $425 \mathrm{~mm}$ (over $1500 \mathrm{~mm}$ in the mountain areas and $200 \mathrm{~mm}$ near the border), mean annual runoff of the river at the town of Gode in Ethiopia is $3387 \mathrm{Mm}^{3}$ [7], and at the town of Belet-Weyne in Somalia is $2384 \mathrm{Mm}^{3}$ [8]. About 1,000 million $\mathrm{m}^{3}$ is lost in the Ogaden desert in eastern Ethiopia. The river runoff is totally generated by catchments within Ethiopia [7, 8]. The river has a high saline content even during high flows.

Due to its climate conditions, the basin is frequently affected by droughts and floods causing major problems to mainly downstream communities in Somalia.

The basin contains other unexploited but discovered natural resources such as minerals, petroleum and natural gas. The basin has also livestock resources.

\subsection{The Juba river}

Like the Shabelle, the Juba River originates from the Ethiopian Highlands, where three large tributaries, the Genale, the Dawa and the Weyb (Gestro), meet near the border with Somalia to form what is known the Juba River inside Somalia. The Dawa river forms part of Ethiopia-Kenya border. The Juba has a basin area of $452000 \mathrm{~km}^{2}$ [6]. The basin includes also the Laag Dheera sub-basin which is mostly in Kenyan territory, see figure 1. The Laar Dheera sub-basin contains several tributaries joining in Somalia. These include the Ewaso Nyiro tributary originating from Mount Kenya, at an altitude of about 5195 meters a.s.l. Within the sub-basin, there is a large transboundary aquifer, the Merti, stretching over the Kenya-Somalia border. The Merti aquifer contains large amount of unexploited groundwater of about $84000 \mathrm{Mm}^{3}$ [9]. The Juba, which enters the Indian Ocean at Kismayo town in southern Somalia, has a total length of 1808 $\mathrm{km}$, of which $840 \mathrm{~km}$ lies in Ethiopia and $1004 \mathrm{~km}$ in Somalia [6].

Rainfall at the source reaches $1600 \mathrm{~mm} / \mathrm{y}$, dramatically decreasing southwards, where the mean reduces to $200 \mathrm{~mm} / \mathrm{y}$ in the areas near the border. The average annual rainfall of the entire basin is about $500 \mathrm{~mm}$. The mean annual runoff of the river in Ethiopia is $6600 \mathrm{Mm}^{3}$ [10] and $6200 \mathrm{Mm}^{3}$ in Somalia [11]. Ethiopia again contributes over 95\% [8, 10, 11]. The Laag Dheera part of the basin is very arid and it seems that the runoff from the sub-basin recharges the Merti aquifer. Kenya is part of the basin but as there are no major surface runoff contributions to the river system, it does not normally contribute to the Jubba, and has no access to the main river channel. Kenya has major interests in the Merti aquifer in the future.

The Jubba river transports substantial volumes of sediment [10].

The two river basins could be considered as one basin with three sub-basins the Shabelle, the Juba and the Laag Dheera. In total, they occupy a land area of $749000 \mathrm{~km}^{2}$ [6]. The total drainage area of the two basins was also previously estimated to $805100 \mathrm{~km}^{2}$ [12]. The rivers generate small amount of runoffs due to the high evapotranspiration and low rainfall. As Somalia's most water resources exist in these rivers, runoff contributions by catchments in Somalia are normally minimal. The effects of this factor will be analysed later in the paper.

The total population in the two basins is about 30 million and the annual population growth rate is over $3 \%[6,10,11]$. 


\section{River developments and economic water uses}

\subsection{Existing water uses in the Juba \& Shabelle river basins}

\subsubsection{Ethiopia}

In upstream areas of Ethiopia, there are currently two major water projects. Melka Wakana hydropower dam with discharge release of $60 \mathrm{~m}^{3} / \mathrm{s}$ was commissioned in 1988 to produce $153 \mathrm{MW}$ [7]. The dam is the only one existing in the basin. Gode irrigation project with $17 \mathrm{~km}$ long canal has the capacity to irrigate 17000 ha of land [7]. The canal, with a discharge capacity of $46 \mathrm{~m}^{3} / \mathrm{s}$, consumes large amount of water in the semi-desert area of Ogaden in eastern Ethiopia greatly affecting downstream flows to Somalia.

There are no currently significant water uses in the Genale-Dawa River Basin in Ethiopia. At the present time, no storage reservoir for hydropower generation or other purposes have been constructed. Agricultural economy is predominantly based on small scale rain-fed subsidence farming and small-scale irrigation schemes for cash crop production. In the highlands, livelihoods are crop production while in the lowlands area where rainfall is inadequate; livelihoods are primarily dependent on livestock production.

\subsubsection{Kenya}

There are no major water uses in Kenyan part of the basin. There is only one medium irrigation scheme adjacent to the Dawa river.

\subsubsection{Somalia}

As the two rivers supply the Somalia's rice bowl and support important economic areas in southern Somalia, several agricultural development projects based on the water resources of the two rivers have been implemented from independence in 1960 until state collapse in 1991. Before 1991, ten barrages and one dam for river regulation with irrigation canals were built to put 161583 ha of land under controlled irrigation [13]. In 1987/88 cropping year there were 112950 ha of irrigated agriculture along the rivers. Inside Somalia, no dam was built on the Shabelle River, but there are many major agricultural developments along the river that intensively use much of the available water. Off-stream facility with storage capacity of $200 \mathrm{Mm}^{3}$ was also built near the town of Jowhar.

Irrigation projects on the Jubba river include the Jubba sugar project (JSP); Mugaambo rice irrigation project and Arare banana irrigation project. Fanole dam project, which is the only dam existing in Somalia has a multipurpose development for irrigation, hydropower and flood mitigation.

As a result of the civil war, all the ten barrages, the Fanole dam and related canals are currently not operational and require major rehabilitation work [14].

\subsection{Planned water uses in the Juba and Shabelle river basins}

\subsubsection{Ethiopia}

According to the Ethiopian river basin master plans in the Wabi Shabelle River Basin, 141 irrigation schemes (25 large, 76 medium and 40 small irrigation 
projects) with net irrigable area of 209310 ha were identified for irrigation development consuming an amount of water estimated to $2566 \mathrm{Mm}^{3}$ available in the basins [7], which is much more than what is available for Somalia at BeletWeyne town. In a three phases irrigation development plans from 2010 to 2035, the first phase will irrigate 26705 ha of land, the second phase 53339 ha, and the third phase 109950 ha.

The master plans, which was finalised in 2005, has also identified six large dams together generating $1000 \mathrm{MW}$ and with combined storage capacities of $10371 \mathrm{Mm}^{3}$. The plans include also water supply for increasing and urbanizing population of 15 millions.

According to the Ethiopian master plans in the Genale-Dawa River Basin, 10 medium and large scale schemes with over a million hectares of potential irrigable land areas were proposed for irrigation consuming a large amount of water available in the basin [10]. After a close study, they were reduced to 10 candidate projects of irrigation. The master plan, which was presented in 2007, identified 22 dam projects for potential hydropower development. After further screening 9 dam projects were shortlisted. These 9 dams will be implemented in different periods of time, stretching from 2013 to 2035. The economic hydropower potential of these dams is estimated to $1300 \mathrm{MW}$. Ethiopia is planning to export hydropower to its neighboring countries to earn desperately needed foreign currency. The plans include also water supply schemes. The planned water-based development projects will cost over 4 billion US\$ [7, 10].

\subsubsection{Kenya}

In Kenya, there are interests of river and groundwater development for irrigation and domestic uses, particularly along the Dawa and the Merti aquifer.

\subsubsection{Somalia}

Before the civil war in 1991, plans were in hand to further increase utilisation of the water resources in the two rivers. As the capacity to expand irrigation schemes remained high, development of over 250000 ha of controlled irrigation were proposed [15]. In the Shabelle basin, irrigation schemes totaling 33500 ha were planned. The proposed irrigation development demanded $1175 \mathrm{Mm}^{3}$ of water [15] which could be available in the river. This was based on no-irrigation developments in Ethiopia.

In the Jubba river basin, Somalia has in 1989 completed the Jubba valley development master plan, which produced country's largest ever-planned development project, the Baardheere dam project (BDP). Regarded as a vital step towards food self-sufficiency and energy production, which received priority in development planning, the multipurpose dam with its $5700 \mathrm{Mm}^{3}$ reservoir would irrigate 120000 ha, produce $140 \mathrm{MW}$ hydroelectric power and mitigate floods [11]. The BDP did not materialize for many reasons. Ethiopia objected the BDP in 1987 and argued that the dam will cause appreciable harm to their interests as they have the potential to impound all river discharges [16]. In the new master plan of the Genale-Dawa, Ethiopia is planning to build large dams similar to the BDP with the capacity to inundate the entire annual river runoff for irrigation and hydropower generation. This will obviate the BDP. 
Somalia's proposed irrigation developments in the Jubba basin demand 4654 $\mathrm{Mm}^{3}$ of water while $75 \%$ of the natural stream flow provides $3935 \mathrm{Mm}^{3}$ [15]. Consumptive uses in Ethiopia was estimated to $2400 \mathrm{Mm}^{3}$ of water.

\section{Analysis of transboundary water issues of the rivers}

\subsection{Historical conflict and current issues}

The relations between Ethiopia and Somalia were complicated particularly in view of their long history of animosity, mistrust, conflict and border dispute, which resulted from the demarcations by the European Colonialists during $19^{\text {th }}$ and $20^{\text {th }}$ centuries. During that period, Ethiopia played a key role in the colonial division of the Somali Plateau into five areas. These tense relations resulted political conflict which led to two military wars in 1964 and 1977. Relation between Somalia and Kenya was also uneasy since independence in 1960.

Since Somalia's state collapse in 1991, Ethiopia was accused of supplying weapons to Somalia's functional leaders. Ethiopia occupied and invaded Somalia in 2006 and the Ethiopian troops are inside Somalia since then for different reasons. In the Somali civil war, Ethiopia and Kenya dominated the country's political process and security, many times worsening the situation. Kenya army troops have also entered into Somalia in 2011 and are there since then.

\subsection{Physical and political aspects of the rivers}

Ethiopia dominates the river basins in terms of basin area, river runoff as well as geographic position and population. Somalia is however the major water user in the basins. Despite living in different countries, majority of the river basins' population are ethnically Somalis.

Despite being the largest basin of Ethiopia's twelve basins, covering one-fifth of country's territory, the Shabelle has the least runoff of all rivers. This meagre resource is a major source of water for Somalia and one of the limiting factors for its development. The Juba is the third largest basin in Ethiopia with less runoff compared to other basins in Ethiopia, but in Somalia is the largest river in terms of river runoff. Somalia is in most disadvantaged position to be in. Table 1 shows land share of basins' area by the riparian countries.

Table 1: $\quad$ Land share of the river basins by riparian countries $\left(\mathrm{km}^{2}\right)$.

\begin{tabular}{|l|r|r|r|r|}
\hline River basin & \multicolumn{1}{|c|}{ Ethiopia } & \multicolumn{1}{|c|}{ Kenya } & \multicolumn{1}{c|}{ Somalia } & \multicolumn{1}{c|}{ Total } \\
\hline Shabelle & 188700 & 0 & 108300 & $\mathbf{2 9 7 0 0 0}$ \\
\hline Jubba-Genale-Dawa & 143650 & 11000 & 66300 & $\mathbf{2 2 1 ~ 0 0 0}$ \\
\hline Laag Dheera & 17000 & 180000 & 34000 & $\mathbf{2 3 1 0 0 0}$ \\
\hline Total, area in km ${ }^{2}$ & $\mathbf{3 4 9 3 5 0}$ & $\mathbf{1 9 1 0 0 0}$ & $\mathbf{2 0 8 6 0 0}$ & $\mathbf{7 4 9 ~ 0 0 0}$ \\
\hline Total, \% & $46 \%$ & $26 \%$ & $28 \%$ & $100 \%$ \\
\hline
\end{tabular}

Source: developed on data from [6]. 
As the rivers cross over disputed border between Ethiopia and Somalia, BeletWeyne and Luuq towns are the most important points where the rivers' flow and their water quality could be observed in Somalia. Kenya is part of the basin but as there are no major surface runoff contributions, it does not normally contribute to the Juba River, and has no access to the main river thus any significant interests. The two river basins cover geographically one-third of each riparian country's total land area. Unlike other riparian countries, the basins occupy Somali's most populated and most important economic areas where even future economic developments are needed to take place. Somalia is currently the major user of the two rivers' water resources and has plans to further increase the utilization of the water resources in the rivers.

One of the main problems experienced but also facing the river basins has its roots in limited availability of the water resources, in relation to existing and increasing demands pattern.

\subsection{Importance of the rivers in Somalia's economy and ecology}

The Juba and Shabelle Rivers are important resource bases for Somalia, as they supply country's rice bowl. Traditional socio-economic activities in southern Somalia are strongly based on the availability of water in the two rivers. Water resources in the two rivers are strongly linked to the survival of the Somali national economy as well as its social and environmental well-being. The rivers are vital to the well-being of the nation [15]. Somalia lacks significant alternatives to the two rivers as long as water development for agricultural productions is concerned. The rivers pass through ecologically sensitive areas of both inland and coastal ecosystems.

\subsection{River development projects in Ethiopia}

Since Ethiopia has not been using water resources of the rivers, the Ethiopian master plans of the Wabi Shabelle and Genale-Dawa river basins reveal that the proposed major increase in agricultural and energy productions in Ethiopia demands large scale mobilisation of the water resources in the rivers. The proposed large dams and irrigation schemes have the capacities to utilise all available water resources in the two rivers, leaving no water for existing downstream uses in Somalia. As an outcome from the master plans, Ethiopia has decided to irrigate large areas of land in order to increase its desperately needed agricultural production. Ethiopian hydropower development plans through building large dams on the rivers create opportunities to earn foreign currency by selling hydropower energy to neighbouring countries, particularly Kenya.

\subsection{Ethiopian policies, water projects and effects on Somalia}

Ethiopia has, after the overthrown of the military regime in 1991, gone into a new process of planning of its internally available water resources, adopted two policies which will have great impacts on its shared rivers including the Juba and Shabelle rivers. These are food self-sufficiency and policy of energy production 
based on hydropower development. Food self-sufficiency policy demands total increase of utilization of internally available water resources for food production through establishing new large irrigation schemes, which will decrease river flows for downstream uses. The country decided also to base all its energy production on hydropower, requiring large dam buildings on Ethiopia's major rivers. These dam developments will adversely impact on downstream uses in Somalia. Since irrigation is a major consumptive user of water, the Ethiopian irrigation plans in the very dry areas in the middle reaches of the river basins will demand large amount of water. This cause not only significant reduction of water flow to Somalia but also dries up the entire river flows.

The effect of these policies will be that they will increase the fears that Somalia has in these shared rivers, as Ethiopia can theoretically divert and control the water resources in the Jubba and Shabelle rivers. Diversion of water for major consumptive uses such as irrigation in upstream areas of the basins will cause have two major adverse impacts on Somalia:

1. Economic effect: existing irrigation schemes will collapse.

2. Ecological effect: river ecology, wetlands in the Shabelle depression areas and the seawater intrusion in at the mouth of the Juba estuary.

In terms of river flows, large dams for hydropower production in upstream areas will regulate the water flows in downstream areas of the rivers. Somalia may benefit from these river regulations, as they will increase dry period flows.

Concerning the Ethiopia's proposed water projects, Somalia has not been notified and Ethiopia argues that there is no central government to notify and cooperate with. In contrary to that argument, Ethiopian troops went in into Somalia in 2006 with an agreement with the transitional government at the time.

\subsection{Ethiopian arguments and international water principles}

In view of the internationally accepted water principles, Ethiopia's arguments are mainly based on only the principle of reasonable and equitable utilisation, while the country avoids to endorse the principle of not to cause significant harm [10]. The "No-harm" principle was perceived as an obstacle to its planned development favouring downstream uses. In the master plans of the rivers, where they analysed the effect of these principles, Ethiopia showed clear reluctance to the UN Convention on the laws of non-navigational uses of the international watercourses, and preferred to apply to the Helsinki Rules.

It is worth to note that in 1997 when the convention was introduced to the UN member states, Ethiopia and Kenya were present at the meeting while Somalia was absent. Kenya voted in favor of the UN Convention while Ethiopia abstained. No countries has signed or ratified the Convention.

\subsection{Complementarities of region's resources}

Prospects for hydropower development in upstream areas and irrigation development in downstream areas of the basins are significant. In addition, Ethiopia is in desperate need in access to the sea while Somalia has plenty of ports which can supply Ethiopia. Somalia's economy is totally dependent on 
reliable access to the water in the rivers. With its unexploited natural and economic resources, complementarity of the region's resources is very high.

\subsection{Incompatibility of the policies and plans}

Somalia developed the Juba and Shabelle rivers as its own national rivers within its national territory. In its master plans, Ethiopia has similarly planned to develop the entire waters of the two rivers as they are national rivers. These unilateral actions imply and reflect policies of no-will-for-cooperation.

Agriculture is by far the most important socio-economic activity sector in the basins. Development of the agricultural sector is therefore of high importance to the economy of the three riparian countries of the Juba and Shabelle basins. Ethiopia and Somalia has development policy based on agricultural development through irrigation, it therefore seems incompatible to reconcile their competing and conflict needs. Both countries developed major plans for irrigation, which demand more non-existing water supplies from the rivers.

\subsection{Growing water scarcity and looming water conflict}

Joining water scarce countries in the world, all countries in the Juba and Shabelle basins passed the point defined to indicate severe water stress and water deficit, where water scarcity effectively limits further development. Under these water scarcity conditions, high level of technology and large-scale irrigation will be necessary in order to increase the needed yield of food production. Due to their climate and population growth, the countries experience both natural and demographic water scarcities.

The amount of water that Ethiopia has planned to divert to irrigation development, in the case of the Shabelle, is much more than what is available in Somalia. Somalia has expressed their need and capacity to absorb all readily useable water resources for existing and future irrigation in the Shabelle [15]. A small increase in consumptive of the Shabelle in Ethiopia will greatly affect not only future demands but also the existing water uses. According to Ethiopia master plans, large amount of water will be utilized for irrigation. Ethiopia has literally stated that the demand will become competitive and conflict will begin to rise [10]. With its geographical position of upstream, Ethiopia threatened to use first-come first-served principle. Somalia may then claim priority over Ethiopia by applying first-in-time first-in-right within prior appropriation principle. Somalia is in deep concern over the sensitivity of the river systems, as any small increase in consumptive use of the rivers in Ethiopia will compromise not only Somalia's future uses but also their existing irrigation schemes.

Considering the existing and proposed water development projects and taking into account the limited amount of the rivers' water resources, the sum all demands are likely to exceed available supplies, it is certain that there is a looming water conflict between riparian states. 


\section{Required river cooperation and its major obstacles}

\subsection{Obstacles and reasons to desperately needed river cooperation}

Issues that are obstacles to establishing river cooperation aiming at resource sharing and common management are many. These include severity of the water scarcity in the riparian countries, geographical balance of the problem, historical conflicts and current tensions, growing population, and the border disputes. One of the major obstacles to establishing is the lack of central and functional system of government in Somalia for the last two decades.

\section{Sharing benefits through river cooperation and regional economic integration}

\subsection{Potential opportunities for common development}

Since the two rivers lack currently major water infrastructures, there are potential opportunities for making better planning and development. From engineering and economic development of the resources point of view, water should be developed where it can give highest economic return. The best approach for making this evaluation is basin approach which is the best planning and management unit. The upper reaches of the rivers are suitable for hydropower development while the downstream areas suit for irrigation development. This joint river planning will also create opportunities for integrating several economic sectors such as water, agriculture, livestock and energy.

\subsection{Regional economic integration - the optimal solution}

One opportunity that demands political commitments but could be explored is to go into regional economic integration. Other economic issues than water will therefore be necessary to be included in the discussions. Being the world's largest landlocked nation, Ethiopia is in a desperate situation regarding its lack of a reliable outlet access to the sea for their economy. In view of this, the existing opportunity, which the two countries, Ethiopia and Somalia could mutually benefit, is to allow the two rivers to run into Somalia without major consumptive uses in upstream Ethiopia in exchange to freely accessible ports for Ethiopia in the Somalia's long coastal lines. This economic integration strongly demands commitments that should be made by the two countries assuring a joint security and save co-existence in the future.

\section{Conclusions}

The Juba and Shabelle rivers are in underdeveloped, water-scarce and conflict ravaged region of the Horn of Africa. In both river basins, Ethiopia dominates in many decisive terms. Somalia is a vulnerable end-user located in downstream area, which is the least favorable position to be in, as the upstream basin 
countries of Ethiopia, can theoretically divert and pollute the water in the rivers. This renders Somalia permanently and heavily dependent on the actions taken by Ethiopia. Somalia is in the most disadvantaged position in geographical, hydrological, political and economical terms.

As these shared rivers will play a key role in future relations between Ethiopia and Somalia, the desperate need to initiate cooperation through dialogue based on mutual security is significant and trust needs to be established. The only assurance that no harm is done to the interests of any party lies in the process of collaboration through negotiation, and a useful way to initiate and sustain dialogue is to seek opportunities for mutual benefits. Joint planning of the river basins can give optimal utilization of its water resources for the benefit of its riparian countries and communities.

\section{References}

[1] Delli Priscoli, 1998. Water and civilization: Conflict, cooperation and the roots of a new eco-realism. Stockholm, Sweden. $17 \mathrm{pp}$.

[2] Biswas, Asit, K., (ed.) 1996. Water Resources Management: Environmental Planning, Management, and Development. McGraw-Hill. p.18.

[3] Elhance, Arun, 1999, 'Hydropolitics in the Third World: Conflict and Cooperation in International River Basin'. United States Institute of Peace, Washington, D.C. p. 13, 233.

[4] World Bank, 1998. International Watercourses: Enhancing Cooperation and Managing Conflict. Salman M. A. Salman and Laurence Boisson de Chazournes.

[5] Elmi, M., Abdullahi, and Iman, M., Hussien, 2010. Hydropolitics in the Horn of Africa - Conflict and required cooperation in the Jubba and Shabelle Rivers. In: Shared waters, shared opportunities: Hydropolitics in East Africa (eds.) Bernard Calas and C. A. Mumma Martinon. Nairobi, Kenya. p. 37-52.

[6] FAO-SWALIM, 2010. Atlas of the Juba and Shabelle Rivers in Somalia.Nairobi, Kenya. p.2, 3.

[7] Ministry of water resources, Ethiopia, 2004. Wabi Shebele river basin integrated development master plan study project. Volume I Main report p. 122.

[8] FAO. 1989. A Brief Description Major Drainage Basins Affecting Somalia. Prepared by D. Kammer. National Water Centre, Mogadishu. Project Field Document No. 14. SOM/85/008.

[9] Fred K. Mwango, B.C. Muhangú, C.O. Juma, I. T. Githae, 2002. Groundwater resources in Kenya. Laboratoire des Sciences et Techniques de l'Eau et de l'Environnement. Université de Cocody. Proceeding of the International Workshop. Tripoli, Libya. 2-4 June, 2002.

[10] Ministry of water resources, Ethiopia, 2007. Genale-Dawa river basin integrated resource development master plan study. Lahmeyer International / Yeshi-Ber Consult. Final Report Volume II.1 Hydrology and Climate. p. 64. 
[11] Ministry of Juba Valley Development, Somalia, 1990. Master plan for Juba Valley Development. Annex 1 Water. GTZ . Agrar Und Hydrotechnik GMHB.

[12] Wolf Aaron, T., Natharius, J. A., Danielson, J., J., Ward, B., S., Pender, J., 1999. International River Basins of the World. International Journal of Water Resources Development, Vol. 15, No. 4.

[13] Mbara C.J., Gadain H. M and Muthusi F.M., 2007. Status of Medium to Large Irrigation Schemes in Southern Somalia, Technical Report No W-05, FAO-SWALIM, Nairobi, Kenya.

[14] Basnyat, D. B. and Gadain H. M., 2009: Hydraulic Behaviour of the Juba and Shabelle Rivers: Basic Analysis for Irrigation and Flood Management Purposes. Technical Report No W-13, FAO-SWALIM, Nairobi, Kenya.

[15] Somalia, Democratic Republic, 1979. Present and Future Irrigated Agriculture in the Shabelle and Juba River Basins. By Jean C. Henry, Consultant Hydrologist. FAO, Rome.

[16] Salman, M., Salman, 2011. The Baardhere Dam and Water Infrastructure Project in Somalia-Ethiopia's objection and the World Bank response. Hydrological. Sciences Journal 56(4), 630-640. 